Georgetown University Law Center

Scholarship @ GEORGETOWN LAW

2011

\title{
What is Originalism? The Evolution of Contemporary Originalist Theory
}

Lawrence B. Solum

Georgetown University Law Center, Ibs32@law.georgetown.edu

This paper can be downloaded free of charge from:

https://scholarship.law.georgetown.edu/facpub/1353

http://dx.doi.org/10.2139/ssrn.1825543

This open-access article is brought to you by the Georgetown Law Library. Posted with permission of the author. Follow this and additional works at: https://scholarship.law.georgetown.edu/facpub

Part of the Constitutional Law Commons, Legal History Commons, and the Legal Theory Commons 


\title{
WHAT IS ORIGINALISM? THE EVOLUTION OF CONTEMPORARY ORIGINALIST THEORY
}

\author{
Lawrence B. Solum
}

\section{Introduction}

Debates over "originalism" have been a central focus of contemporary constitutional theory for three decades. One of the features of this debate has been disagreement about what "originalism" is. More worrisome is the possibility that the arguments between contemporary originalists and their opponents, the "living constitutionalists", are confused - with each side of the debate making erroneous assumptions about the content of their opponent's theories.

The aim of this chapter is to clarify these debates by providing a history of contemporary originalism and then developing an account of the core or focal content of originalist theory. The history reveals that contemporary originalist theory has evolved - the mainstream of originalist theory began with an emphasis on the original intentions of the framers but has gradually moved to the view that the "original meaning" of the constitution is the "original public meaning" of the text. Even today, originalists disagree among themselves about a variety of important questions, including the normative justification for a constitutional practice that adheres to original meaning. Despite evolution and continued disagreement, however, contemporary originalist theory has a core of agreement on two propositions. First, almost all originalists agree that the linguistic meaning of each constitutional 
provision was fixed at the time that provision was adopted. Second, originalists agree that our constitutional practice both is (albeit imperfectly) and should be committed to the principle that the original meaning of the Constitution constrains judicial practice. The question whether living constitutionalists actually disagree with these core principles of originalist theory is a complex one - to which we shall return at the end of this chapter.

\section{A Word About the Word: The Origins of "Originalism"}

The first appearance of the term "originalism" in Westlaw's database of legal periodicals is found in an article by Paul Brest in $1981,{ }^{1}$ but Brest had used both "originalism" and "originalist" in $1980^{2}$ (in an article that is not included in the data base). So far as Brest knows, he coined the word. ${ }^{3}$ Here is how Brest defined "originalism":

By "originalism" I mean the familiar approach to constitutional adjudication that accords binding authority to the text of the Constitution or the intentions of its adopters. 4

The disjunctive "or" in the last clause of Brest's definition presaged a debate among originalists, but what is most striking about this passage is Brest's assumption that his audience already understood the features of the view that he was about to criticize. Brest's neologism caught on, and the words "originalism" and "originalist" appear frequently from 1981 onward. ${ }^{5}$

\footnotetext{
${ }^{1}$ Paul Brest, "The Fundamental Rights Controversy: The Essential Contradictions of Normative Constitutional Scholarship", 90 Yale L.J. 1063 at 1090 (1981).

${ }^{2}$ Paul Brest, "The Misconceived Quest for the Original Understanding", 60 B.U.L. Rev. 204 at 234 (1980) [Brest, "Misconceived Quest"].

${ }^{3}$ Email exchange between Lawrence B. Solum and Paul Brest, December 2, 2009.

${ }^{4}$ Brest, "Misconceived Quest", supra note 2 at 204.

${ }^{5}$ For example, a search on Google's Books Ngram Viewer reveals no use of the term before 1980 and a steady increase in use of the word "originalism" in books published after the early 1980s. See http://ngrams.googlelabs.com/graph?content=Originalism\&year start=1975\&year end $=2008$ \& corpus $=0$ \& smoothing $=3$ (search for "originalism" from 1975 to 2008 in the "English" database on Google Books).
} 
Whatever the origins of the terms "originalism" and "originalist," scholarly usage of related phrases extends at least as far back as the 1930s. The phrase "original meaning" was used in the constitutional context in a Yale Law Journal article in 1938 discussing the controversy over "substantive due process":

There would be far greater advantage in restoring the original meaning of the 'privileges and immunities' clause and by the process of inclusion and exclusion letting the country know what are now federal privileges, than in forcing the court to draw upon the fathomless depths of the 'due process' clause to give effect to their personal convictions of economic and social propriety. ${ }^{6}$

It is perhaps no coincidence that the original meaning of the Privileges or Immunities Clause continues to hold the constitutional stage 70 years later.

The related phrase "original intentions" appeared in 1938, in a closely related context:

Wholly apart from Bingham's personal understanding of his phraseology, his original intentions in drafting it, or the relations existing between the Cleveland and Mahoning Railroad and other members of the Joint Committee, it is possible that Reverdy Johnson, in the course of the Committee's deliberations, or perhaps even in private conversation with Conkling, mentioned Justice Grier's decision as among the most recent involving the due process clause, and in this manner precipitated a frank discussion of the entire problem of corporate rights. ${ }^{7}$

And "original understanding" made its first appearance in the Westlaw database in a well-known 1949 article by Charles Fairman. ${ }^{8}$

Judicial usage of the "originalism" and the associated phrases "original meaning," "original intentions," and "original understanding" in a

${ }^{6}$ Edwin Borchard, "The Supreme Court and Private Rights" 47 Yale L.J. 1051 at 1063 (1938).

${ }^{7}$ Howard Jay Graham, "The "Conspiracy Theory" of the Fourteenth Amendment" 48 Yale L.J. 171 at 189-90 (1938) (citation omitted).

${ }^{8}$ Charles Fairman, Does the Fourteenth Amendment Incorporate the Bill of Rights?: The Original Understanding" 2 Stan. L. Rev. 5 at 5 (1949) (exploring the meaning of the Fourteenth Amendment's clauses "at the time the Amendment was adopted"). 
constitutional context seems to post-date academic usage. The first use of the phrase "original meaning" in the text (exclusive of citations) of an opinion by a Supreme Court Justice occurred in Justice Black's dissent in Harper v. Virginia State Bd. of Elections ${ }^{9}$ in 1966 :

Since the Breedlove and Butler cases were decided the Federal Constitution has not been amended in the only way it could constitutionally have been, that is, as provided in Article V of the Constitution. I would adhere to the holding of those cases. The Court, however, overrules Breedlove in part, but its opinion reveals that it does so not by using its limited power to interpret the original meaning of the Equal Protection Clause, but by giving that clause a new meaning which it believes represents a better governmental policy. From this action I dissent. ${ }^{10}$

The first similar occurrence of "original meaning" in a majority opinion occurs in a footnote in Justice Powell's 1977 opinion for the Court in Ingraham v. Wright. ${ }^{11}$ "Original understanding” made its first similar appearance in Justice Harlan's 1970 dissent and concurrence in Oregon v. Mitchell. " "Original intentions" first occurs in Justice Berger's 1983 dissent in Solem v. Helm. ${ }^{13}$ The term "originalist" first occurred in Justice Scalia's 1995 dissenting opinion in Roper v. Simmons, ${ }^{14}$ and "originalism" made its first appearance in Justice Stevens' 2005 dissenting opinion in Van Orden $v$. Perry. $^{15}$

The word "originalism" is a neologism-a word that was coined for the purpose of carving up theoretical space. Brest's original usage introduced an ambiguity by referring to "text" or "intentions." In addition, Brest's new word resonated-presumably this was deliberate-with other phrases with long histories of usage in a variety of legal contexts ("original meaning," "original

\footnotetext{
${ }^{9} 383$ U.S. 663 at 671 (1966)

${ }^{10}$ Ibid.. at 671-2.

${ }^{11}$ Ingraham v. Wright, 430 U.S. 651 at 670 n. 39 (1977).

12400 U.S. 112 at 165 (1970).

${ }^{13} 463$ U.S. 277 at 310 (1983).

14543 U.S. 551 at 626 (1977).

15545 U.S. 677 at 729 (2005).
} 
understanding," and "original intention"). Moreover, Brest used the terms "originalism" and "originalist" in order to refer to a position that he was criticizing. Brest's term caught on, and eventually was adopted by proponents of the views that had affinities with the object of his critique. As a consequence, the words "originalism" and "originalist" are ambiguous-used by scholars, lawyers, judges, and the public in a variety of different ways. It seems likely that as a matter of lexicography, "originalism" is a family resemblance term-with several overlapping senses.

This deep ambiguity in the meaning of originalism is further complicated by the sociology of the legal academy and the politics of judicial interpretation. Legal theorists who self-identify as originalists are likely to strive to police the boundaries of the "originalism," seeking to exclude implausible views and to focus debate on the versions of originalism that they believe are true, correct, or most reasonable. Legal theorists who oppose originalism may have precisely the opposite motivation, seeking to identify originalism with its least defensible variations. Political champions of originalism are likely to focus on simplified "sound bite" versions of the theory that conflate the content of originalist theory with the goals it seeks to achieve: "Originalism is the theory that judges should follow the law and not make it." Likewise, political opponents might define originalism as a view that is obviously unpalatable: "Originalism is anti-woman."

For all these reasons, the road to conceptual clarity in debates about originalism will be rocky. The quest for agreement on a single definition of originalism is likely to prove Quixotic. For this reason, stipulated definitions of originalism should be avoided. Readers of theoretical texts are imperfect, and the stipulated meaning of "originalism" is likely to be ignored or 
forgotten. A more promising approach should begin with the facts. "Originalism" is an ambiguous theoretical term. There is a family of originalist constitutional theories. In order to make progress in the debates about "originalism," we will need to map the theoretical space, identifying the ways in which different versions of originalism vary and the ways in which they resemble one another.

\section{A Very Short History of Contemporary Originalist Theory}

The first step towards an answer to the question, "What is originalism?," was an investigation of the origins of the word "originalism." The second step is a history of the theories that are associated with that word. The history that is offered here is necessarily brief, partial, and incomplete. A complete version of the story would require a long monograph. The aim of the very short history in Part III is to identify the most important theoretical developments, with an emphasis on the developments that are most relevant to the current state of originalist theory. ${ }^{16}$

\section{A. Original intentions of the framers}

Contemporary debates about originalism trace back to the early 1970 s. In 1971 Robert Bork wrote "Neutral Principles and Some First Amendment Problems", ${ }^{17}$ an article that is sometimes considered the opening move in the development of contemporary originalist theory. Bork's essay was only

\footnotetext{
${ }^{16}$ For a different view from an earlier time, see Daniel A. Farber, "The Originalism Debate: A Guide for the Perplexed", 49 Ohio St. L.J. 1085 at 1085 (1989) (offering a concise "tourist guide" introduction to the "original intent" debate).

17 Robert H. Bork, "Neutral Principles and Some First Amendment Problems", 47 Ind. L.J. 1 (1971).
} 
loosely "originalist" in the contemporary senses of that term. The following passage is representative:

There appear to be two proper methods of deriving rights from the Constitution. The first is to take from the document rather specific values that text or history show the framers actually to have intended and which are capable of being translated into principled rules. We may call these specified rights. The second method derives rights from governmental processes established by the Constitution. These are secondary or derived individual rights. This latter category is extraordinarily important. This method of derivation is essential to the interpretation of the first amendment, to voting rights, to criminal procedure and to much else. ${ }^{18}$

The emphasis on "text" and "history" is recognizably originalist, but Bork's notion of "derived rights" is not clearly anchored in original meaning or original intentions.

In 1976, then-Associate Justice William Rehnquist authored "The Notion of a Living Constitution", which, based on the writings of the Framers, explicitly criticized living constitutionalism and implicitly endorsed originalism. ${ }^{19}$ A year later, in 1977, Raoul Berger penned Government by Judiciary, ${ }^{20}$ which argued that the Supreme Court's interpretations of the Fourteenth Amendment were contrary to the original intentions of its Framers. In 1985, then-Attorney General Edwin Meese put originalism on the political agenda in a well-publicized speech before the American Bar Association. ${ }^{21}$ Meese's speech included the following passage:

${ }^{18}$ Ibid. at 17 .

19 William H. Rehnquist, "The Notion of a Living Constitution", 54 Tex. L. Rev. 693 (1976).

${ }^{20}$ Raoul Berger, Government by Judiciary (1977).

21 See Edwin Meese III, "Speech Before the American Bar Association" (July 9, 1985), reprinted in The Great Debate: Interpreting Our Written Constitution (Paul G. Cassel ed., 1986), online: $<$ http://www.fed-soc.org/resources/id.49/default.asp $>$ [Meese, "Speech Before the American Bar Association"]; see also Edwin Meese III, "The Case for Originalism", The Heritage Foundation (June 6, 2005) online:<http://www.heritage.org/Press/Commentary/ed060605a.cfm>; Lynette Clemetson, "Meese's Influence Looms in Today's Judicial Wars", N.Y. Times, Apr. 17,2005 , at A1. 
In reviewing a term of the Court, it is important to take a moment and reflect upon the proper role of the Supreme Court in our constitutional system. The intended role of the judiciary generally and the Supreme Court in particular was to serve as the "bulwarks of a limited constitution." The judges, the Founders believed, would not fail to regard the Constitution as "fundamental law" and would "regulate their decisions" by it. As the "faithful guardians of the Constitution," the judges were expected to resist any political effort to depart from the literal provisions of the Constitution. The text of the document and the original intention of those who framed it would be the judicial standard in giving effect to the Constitution. ${ }^{22}$

Bork, Rehnquist, Berger, and Meese did not develop anything that approaches a full-blown constitutional theory, but their views suggested something like the theory we now call "original intentions originalism," the view that the original intentions of the Framers should guide constitutional interpretation.

\section{B. The misconceived quest and the original understanding of original} intentions

Following Berger's book, but five years before Meese's speech, Paul Brest wrote "The Misconceived Quest for the Original Understanding", ${ }^{23}$ one of the most cited and influential contributions to constitutional theory. ${ }^{24}$ Brest's article advanced a variety of criticisms of original intentions originalism, including: (1) the difficulty of ascertaining the institutional intention of a multimember body in general; ${ }^{25}$ (2) the particular problems associated with identifying the intention of the members of the Philadelphia Convention and the various state ratifying conventions in the case of the original Constitution and of Congress and the various state legislatures in the case of

${ }^{22}$ Meese, Speech Before the American Bar Association, ibid.

${ }^{23}$ Brest, "Misconceived Quest", supra note 2.

${ }^{24}$ A Westlaw search of the JLR database for the string corresponding to the title yielded 719 hits on November 10, 2008.

${ }^{25}$ Brest, "Misconceived Quest", supra note 2 at 214. 
amendments; ${ }^{26}(3)$ the problem of determining the level of generality or specificity of the Framers' and ratifiers' intentions, ${ }^{27}(4)$ the problem of inferring intentions from constitutional structure; ${ }^{28}(5)$ the difficulty of translating the Framers' and ratifiers' beliefs and values given changes in circumstances over time; ${ }^{29}(6)$ the problem of the democratic legitimacy - that is, that the Constitution of 1789 was drafted and ratified without the participation of women and slaves $;^{30}$ and (7) the problem of instability, in that an inflexible constitutional order cannot adapt to changing circumstances. ${ }^{31}$ Brest had much more to say, and there were many other critics of originalism, but this list is sufficient to illustrate the reception that originalism received from constitutional theorists in the late 1970s and early 1980s.

Brest also raised the problem of the Framers' and ratifiers' interpretive intentions, ${ }^{32}$ and his remarks anticipated Jefferson Powell's 1985 article, "The Original Understanding of Original Intent", ${ }^{33}$ Powell's article interrogated the assumption that original intentions originalists believed that the Framers' themselves expected that the Constitution would be interpreted to conform to their intentions. Although Powell conceded that there were references to "original intention" and "intent of the framers" in the constitutional discourse of the Founding era, he argued that those phrases did not represent an early version of original intentions originalism. Instead, he argued that " $\mathrm{t}] \mathrm{he}$ Philadelphia framers' primary expectation regarding constitutional

${ }^{26}$ Ibid. at $214-15$.

${ }^{27}$ Ibid. at $216-17$.

${ }^{28}$ Ibid. at 217-18.

${ }^{29}$ Ibid. at 219-22.

${ }^{30}$ Ibid. at 230.

${ }^{31}$ Ibid. at 231.

${ }^{32}$ Ibid. at 215-16.

${ }^{33}$ H. Jefferson Powell, "The Original Understanding of Original Intent", 98 Harv.

L. Rev. 885 (1985). 
interpretation was that the Constitution, like any other legal document, would be interpreted in accord with its express language. ${ }^{34}$ Both the evidence for Powell's thesis and its implications are controversial, but its effect on scholarly opinion was profound. The strongest implication of the article is that original intentions originalism is a self-effacing theory because it requires that the Framers' intentions regarding interpretation be respected, but those intentions require that the Framers' intentions be disregarded.

Brest and Powell were hardly the only critics of original intentions originalism, but their arguments, combined with others, were important in forming the scholarly consensus of the era. ${ }^{35}$ Essentially, that consensus accepted the claim that the original intentions of the Framers could not serve as the basis for a viable theory of constitutional interpretation and construction. $^{36}$

\section{Original understanding of the ratifiers}

During this period, the originalism debate took a brief detour into a variant of original intentions originalism that emphasized the understanding $\mathrm{s}^{37}$ or

${ }^{34}$ Ibid. at 903.

${ }^{35}$ This is not an intellectual history of the originalism debates, and I am not claiming that either Brest or Powell articulated the first or best version of the claims they made. No string cite can do justice to the literature. There were many influential critics of original intentions originalism; one of the most important was Ronald Dworkin. See Ronald Dworkin, "The Forum of Principle”, 56 N.Y.U. L. R. Rev. 469 at 470 (1981).

${ }^{36}$ Randy E. Barnett, "An Originalism for Nonoriginalists", 45 Loy. L. Rev. 611 (1999) ("The received wisdom among law professors is that originalism is dead.") [Barnett, "An Originalism for Nonoriginalists"].

${ }^{37}$ See Richard H. Fallon, Jr., "Judicially Manageable Standards and Constitutional Meaning", 119 Harv. L. Rev. 1275 at 1317 (1996) (defining "originalism" as "the theory that the original understanding of those who wrote and ratified various constitutional provisions determines their current meaning") [Fallon, "Manageable Standards"]. 
intentions of the ratifiers - either the state ratifying conventions understood as corporate bodies or of the individuals who attended the ratifying conventions and voted in favor of ratification. ${ }^{38}$

We need not tarry long over this twist in the debate. The move to ratifiers' understanding or intent is best understood in conjunction with popular sovereignty as a justification for originalism. The ratifiers, rather than the Framers, could plausibly be viewed as expressing the political will of "We the People." However, all of the problems that attended the equation of constitutional meaning with Framers' intent seem to attach to ratifiers' intent. Moreover, evidence may be even more difficult to obtain ${ }^{39}$ and the problems of group intention - of multiple conventions with multiple members - even more confounding with respect to ratifiers' intent. To the extent that the ratifiers' understanding is rooted in the public meaning, the emphasis on ratifiers is merely a way station on the journey from original intentions to original public meaning. ${ }^{40}$

${ }^{38}$ See Charles A. Miller, The Supreme Court and the Uses of History (1969) at 157-88 (arguing that originalism should look to the intent of the ratifiers as well as of the Framers); see also Charles A. Lofgren, "The Original Understanding of Original Intent", 5 Const. Comment. 77 at 113 (1988) ("Indeed, it is not too much to say that at least some of the founders saw the ratifiers' historical or subjective intent as a check on constructions which cut loose from the original understandings of the sovereign people.").

${ }^{39}$ See Henry P. Monaghan, "Our Perfect Constitution", 56 N.Y.U. L. Rev. 353 at 375 n.130 (1981) ("Although the intention of the ratifiers, not the Framers, is in principle decisive, the difficulties of ascertaining the intent of the ratifiers leaves little choice but to accept the intent of the Framers as a fair reflection of it.").

40 Similar points could be made about what might be called "popular meaning," the view that the relevant intentions or understandings should be those of "We the People" or the popular sovereign - the relevant actor for popular constitutionalism. If the relevant intentions are those of each and every citizen, then popular constitutionalism suffers from compounded versions of the ills that afflict intentionalism. If popular constitutionalism points to public meaning, then it is simply another version of original-meaning originalism. For discussion of popular constitutionalism, see Larry Kramer, The People Themselves: Popular Constitutionalism and Judicial Review (2004); see also Larry Alexander \& 
D. We the people

The year before Meese gave his speech to the American Bar Association and Jefferson Powell wrote about the original understanding of original intent, Bruce Ackerman delivered his Storrs Lectures, entitled "Discovering the Constitution", at Yale Law School. ${ }^{41}$ It was in these lectures that Ackerman's theory of constitutional politics made its first wide impression on the community of constitutional scholars. Ackerman's theory distinguishes ordinary politics - what happens when state legislatures and Congress enact statutes, for example - from constitutional politics. Here is the very first statement of Ackerman's view, dualism, in the second lecture:

$[\mathrm{T}]$ he Federalist elaborates a dualistic conception of political life. One form of political action - I shall call it constitutional politics - is characterized by Publian appeals to the common good, ratified by a mobilized mass of American citizens expressing their assent through extraordinary institutional forms. Although constitutional politics is the highest kind of politics, it should be permitted to dominate the nation's life only during rare periods of heightened political consciousness. During the long periods between these constitutional moments, a second form of activity - I shall call it normal politics - prevails. Here, factions try to manipulate the constitutional forms of political life to pursue their own narrow interests. Normal politics must be tolerated in the name of individual liberty; it is, however, democratically inferior to the intermittent and irregular politics of public virtue associated with moments of constitutional creation. ${ }^{42}$

Ackerman's theory served as an answer to Alexander Bickel's countermajoritarian difficulty: the problem of democratic legitimacy that attends judicial review by unelected judges. ${ }^{43}$ Judges as faithful agents of the "We the People," who legislate in rare constitutional moments - or later

Lawrence B. Solum, “Popular? Constitutionalism?”, 118 Harv. L. Rev. 1594 (2005) (book review).

${ }^{41}$ Bruce A. Ackerman, "The Storrs Lectures: Discovering the Constitution", 93

Yale L.J. 1013 (1984) [Ackerman, "Discovering the Constitution"].

${ }^{42}$ Ibid. at 1022-23 (citations omitted).

${ }^{43}$ See generally Alexander M. Bickel, The Least Dangerous Branch: The Supreme Court at the Bar of Politics (1962); see also Kenneth D. Ward \& Cecilia R. Castillo, eds., The Judiciary and American Democracy: Alexander Bickel, the Countermajoritarian Difficulty and Contemporary Constitutional Theory (2005). 
"periods" - act more democratically than do legislators, who serve special interests and escape the people's attention during the extended periods of ordinary politics.

As developed in the Storrs Lectures, Ackerman's theory focused on three constitutional moments: the Founding (the Constitution of 1789), Reconstruction (the Thirteenth, Fourteenth, and Fifteenth Amendments), and the New Deal. Here is the initial appearance of that idea in the lectures:

Speaking schematically, this historical story is dominated by three peaks of high importance that tower over valleys full of more particular meanings. The first peak, of course, is the Founding itself: the framing of the original Constitution and the Bill of Rights, Marbury v. Madison and McCulloch v. Maryland. The second peak is constituted by the legal events surrounding the Civil War: the judicial failure in Dred Scott and the constitutional affirmations of the Civil War Amendments. The third peak centers around the legitimation of the activist welfare state: the long Progressive struggle against judicial resistance and the dramatic capitulation by the Old Court before the New Deal in 1937. Time and again, we return to these moments; the lessons we learn from them control the meanings we give to our present constitutional predicaments. $^{44}$

Because Ackerman's theory purported to legitimize progressive New Deal constitutionalism, his view might have been construed as the polar opposite of originalism, but at a deep level, Ackerman's theory seemed to require an account of original meaning. Without employing original meaning, judicial enforcement of the Constitution could not be legitimized by democratic constitutional politics. In other words, a theory of original meaning is required for constitutional content to be determined by "We the People."

Ackerman's development of popular sovereignty theory has been extraordinarily influential, and others have contributed important work in this

44 Ackerman, "Discovering the Constitution", supra note 41 at 1051-52. 
vein, ${ }^{45}$ prominently Akhil Reed Amar, ${ }^{46}$ Ackerman's colleague at Yale Law

School. Cass Sunstein has described Amar's position in the following terms:

[I]n the law schools the most influential originalist may be Akhil Reed Amar, an ingenious and prolific scholar at Yale Law School. Describing himself as a "textualist" who is interested in history, Amar is methodologically quite close to Scalia. He is intensely interested in the text and in the historical record, and he is generally searching for the original meaning of contested terms. Amar wishes to know what the Constitution "really means," and he puts that question as if it were largely or entirely a matter of excavation. ${ }^{47}$

Although Sunstein's interpretation of Amar is surely plausible, characterizing Ackerman and Amar's theoretical position in originalist terms is problematic, in no small part because they both eschew explicit theorizing about constitutional interpretation. Nevertheless, even if Ackerman and Amar do not describe their views as originalist, it is clear that their approaches to the Constitution, which emphasize popular sovereignty and the constitutional text, have had both direct and indirect influences over contemporary theoretical debates explicitly concerned with originalism..$^{48}$

45 See, e.g., Kurt T. Lash, "A Textual-Historical Theory of the Ninth Amendment", 60 Stan. L. Rev. 895 (2007) [Lash, “A Textual Historical Theory”]; Kurt T. Lash, "Originalism, Popular Sovereignty, and Reverse Stare Decisis", 93 Va. L. Rev. 1437 (2007) [Lash, "Originalism”].

46 See Akhil Reed Amar, America's Constitution: A Biography (2005); Akhil Reed Amar, The Bill of Rights (1998).

47 Cass R. Sunstein, "Originalism for Liberals", The New Republic, Sept. 28, 1998, at 31, online: $<$ http://home.uchicago.edu/ csunstei/originalism.html $>$ (reviewing Amar, The Bill of Rights, ibid, and Akhil Reed Amar \& Alan Hirsch, For the People (1998)).

48 Thus, it is no accident that Amar and Ackerman's students describe themselves as originalists. See, e.g., Lash, "A Textual-Historical Theory”, supra note 45 at 900 ("I will consider the historical record and attempt to identify which of the possible textual meanings are more or less plausible, given historical evidence of original public understanding. In this way, I hope to provide an account of the Ninth Amendment satisfactory in terms of both originalism and textualism."). 


\section{E. Original public meaning and the new originalism}

This sets the stage for what is sometimes called "the New Originalism" $"$ and is also labeled "Original Public Meaning Originalism." ${ }^{150}$ Whatever the actual

origins of this theory, the conventional story identifies Justice Antonin Scalia as having a key role. As early as 1986, Scalia gave a speech exhorting originalists to "change the label from the Doctrine of Original Intent to the Doctrine of Original Meaning." "길 The phrase "original public meaning" seems to have entered the contemporary theoretical debates through the work of Gary Lawson, ${ }^{52}$ with Steven Calabresi as another "early adopter." ${ }^{, 53}$ The core idea of the revised theory is that the original meaning of the Constitution is the original public meaning of the constitutional text.

Randy Barnett ${ }^{54}$ and Keith Whittington ${ }^{55}$ have played prominent roles in the development of the "New Originalism." Both Barnett and Whittington base their theories on a foundation of "original public meaning," but they build upon the views of Scalia and Lawson in a variety of interesting ways.

${ }^{49}$ See, e.g., Keith Whittington, "The New Originalism”, 2 Geo. J.L. \& Pub. Pol'y 599 (2004).

${ }^{50}$ See, e.g., Randy E. Barnett, “An Originalism for Nonoriginalists" supra note 36.

${ }^{51}$ Antonin Scalia, Address Before the Attorney General's Conference on Economic Liberties in Washington, D.C. (June 14, 1986), in Original Meaning Jurisprudence: A Sourcebook 101 at 106 (U.S. Dep't of Justice ed., 1987); see also Caleb Nelson, "Originalism and Interpretive Conventions", 70 U. Chi. L. Rev. 519 at 554-55 (2003) (noting that most originalists have accepted Justice Scalia's suggestion).

52 See Gary Lawson, "Proving the Law”, 86 Nw. U. L. Rev. 859 at 875 (1992). For extended discussions of "original public meaning," see Vasan Kesavan \& Michael Stokes Paulson, "The Interpretive Force of the Constitution's Secret Drafting History", 91 Geo. L.J. 1113 at 1127 (2003); Samuel T. Morison, "The Crooked Timber of Liberal Democracy", 2005 Mich. St. L. Rev. 461 at 465.

${ }^{53}$ See Steven G. Calabresi \& Saikrishna B. Prakash, "The President's Power to Execute the Laws", 104 Yale L.J. 541 at 553 (1994).

${ }^{54}$ See Randy E. Barnett, Restoring the Lost Constitution (2004).

${ }^{55}$ See Keith E. Whittington, Constitutional Construction (1999); Keith E. Whittington, Constitutional Interpretation (1999). 
For the purposes of this very brief survey, perhaps their most important move is to embrace the distinction between "constitutional interpretation," understood as the enterprise of discerning the semantic content of the Constitution, and "constitutional construction," which we might tentatively define as the activity of determining the legal effect of the constitutional text. One mode of construction involves judicial specification of constitutional doctrine when the text is vague, but construction can take place in the political branches as well. ${ }^{56}$ This distinction explicitly acknowledges what we might call the fact of constitutional underdeterminacy: the original meaning of the text does not fully determine constitutional doctrine or its application to particular cases. ${ }^{57} \mathrm{With}$ this turn, original-meaning originalists explicitly embrace the idea that when the original public meaning of the text "runs out," application of the linguistic meaning of the constitutional text to a particular dispute must be guided by something other than original meaning.

Once originalist theory (in some important instantiations) had acknowledged that vague constitutional provisions required construction, this step opened the door for reconciliation between originalism and living constitutionalism. The key figure in that reconciliation has been Jack Balkin through his influential 2006 and 2007 essays “Abortion and Original

56 Another important early adopter of this distinction (in the context of constitutional theory) was Robert Clinton. See Robert N. Clinton, "Original Understanding, Legal Realism, and the Interpretation of "This Constitution", 72 Iowa L. Rev. 1177 (1987).

57 See Lawrence B. Solum, "Semantic and Normative Originalism: Comments on Brian Leiter's 'Justifying Originalism'” Legal Theory Blog, Oct. 30, 2007, $<$ http://lsolum.typepad.com/legaltheory/2007/10/semantic-and-no.html $>$ (observing that conventional semantic meaning of a text can underdetermine its application in several ways); $c f$. Lawrence B. Solum, "On the Indeterminacy Crisis: Critiquing Critical Dogma”, 54 U. Chi. L. Rev. 462 (1987) (distinguishing determinacy, indeterminacy, and underdeterminacy). 
Meaning " 58 and "Original Meaning and Constitutional Redemption". ${ }^{59}$ In these essays, Balkin argued for a reconciliation of original-meaning originalism with living constitutionalism according to a theory that might be called "the method of text and principle." The meaning of the "text" provides a constraining framework within which constitutional "principles" operate. One understanding of Balkin's view is that the "text" requires interpretation and the "principles" are matters of constitutional construction.

Predating much of the American work on the New Originalism was Jeffrey Goldsworthy's work, addressing the Australian Constitution, but developed with an explicit awareness of the theoretical debates swirling around American constitutionalism. Goldsworthy's first major statement, “Originalism in Constitutional Interpretation”, ${ }^{60}$ was published in an Australian law review in 1997. As Goldsworthy's work illustrates, innovations in American constitutional theory may have been anticipated elsewhere and American theorists have no monopoly on the creation of new (or the resurrection of old) theoretical constructs.

\section{F. Original applications and original methods}

Two very recent ideas deserve particular mention: "original applications" and "original methods." The phrase "original applications" or

58 Jack M. Balkin, "Abortion and Original Meaning”, 24 Const. Comment. 291 (2007) [Balkin, “Abortion"].

59 Jack M. Balkin, "Original Meaning and Constitutional Redemption", 24 Const. Comment. 427 (2007) [Balkin, "Original Meaning"].

${ }^{60}$ Jeffrey Goldsworthy, “Originalism in Constitutional Interpretation”, (1997) 25

Fed. L. Rev. 1; and Jeffrey Goldsworthy, "The Case for Originalism" in this volume. See also Lawrence B. Solum, "Goldsworthy on the New Originalism", Legal Theory Blog, Nov. 2, 2007, online:

$<$ http://solum.typepad.com/legaltheory/2007/11/goldsworthy-on-.html>. 
"original expected applications" seems to originate with Jack Balkin, ${ }^{61}$ but Mark Greenberg and Harry Litman articulated similar distinctions between "original meaning" and "original practices" and "meaning" and "application" in their important 1998 article, "The Meaning of Original Meaning". ${ }^{62}$ Although Greenberg and Litman deserve the credit for the deepest and most thorough discussion of the issues, my account here will focus on Balkin's formulation, which brings the idea of original expected applications into the New Originalism, not as a component but rather by way of exclusion.

Greenberg and Litman saw their point primarily as a criticism of originalism; Balkin sees the same issue, but concludes that originalism is strengthened by excluding "original expected applications." ${ }^{\prime 3}$

The distinction is a simple one. The linguistic meaning of a text is one thing, and expectations about the application of that meaning to future cases are a different thing. Balkin makes use of the distinction to argue that some originalists have conflated meaning with expected applications:

Originalists generally assume that if we do not apply the constitutional text in the way it was originally understood at the time of its adoption we are not following what the words mean and so will not be faithful to the Constitution as law. But they have tended to conflate two different ideas - the expected application of constitutional texts, which is not binding law, and the original meaning, which is. Indeed, many originalists who claim to be interested only in original meaning, like Justice Antonin Scalia, have encouraged this conflation of original meaning and original expected application in their practices of argument. ${ }^{64}$

${ }^{61}$ See Jack M. Balkin, “Abortion”, supra note 58, at 293; Jack Balkin, "Original Meaning", supra note 59; Jack Balkin, "Alive and Kicking: Why No One Truly Believes in a Dead Constitution", Slate, Aug. 29, 2005, online:

$<\mathrm{http} / / / \mathrm{www}$. slate.com/id/2125226/>; Jack Balkin, "Clarence Thomas's Originalism”, Balkinization, July 11, 2007, online: $<$ http://balkin.blogspot.com/ 2007/07/clarence-thomass-originalism.html>.

${ }^{62}$ Mark D. Greenberg \& Harry Litman, "The Meaning of Original Meaning”, 86 Geo. L.J. 569 (1998).

${ }^{63}$ Balkin, "Original Meaning”, supra note 59 at 446.

${ }^{64}$ Balkin, "Abortion", supra note 58 at 292-3. 
The fact that original expected applications are distinct from original meanings should not imply that the two are unrelated. Expected applications of a text may offer evidence about its meanings, even if these applications are neither decisive evidence of meaning nor meaning itself.

Of course, some originalists may contest Balkin's move and argue that original expectations originalism is viable. The justification could be that reliance on original expectations is the distinctive characteristic that marks originalist theories as originalist. ${ }^{65}$ But this view appears incorrect given the history of originalist thought, and it is certainly contrary to the theories of New Originalists like Balkin, Barnett, and Whittington.

Another very recent development is the emergence of what might be called "original methods originalism," the view that the original meaning of the Constitution includes the methods of interpretation that the Framers, ratifiers, and/or public of the Founding era could, would, or should have expected to guide constitutional practice. This view is strongly associated with Michael Rappaport and John McGinnis. ${ }^{66}$ They write:

[T] he focus of originalism should be on how a reasonable person at the time of the Constitution's adoption would have understand (sic) its words and thought they should be interpreted. The Constitution's provisions were based on commonly accepted meanings and the interpretative rules of the time. Some of the provisions had clear meanings. Others may have seemed ambiguous, but the enactors would have believed that their future application would be based [on] the interpretive rules accepted at the time. Thus, their assessment of the meaning and the desirability of the Constitution would depend on the interpretive rules that they thought would apply. ${ }^{67}$

${ }^{65} C f$. Christopher L. Eisgruber, Constitutional Self-Government (2001) at 25-6 (characterizing originalism as relying on original expectations).

${ }^{66}$ Their view is stated briefly in John O. McGinnis \& Michael B. Rappaport, "Original Interpretive Principles as the Core of Originalism", 24 Const. Comment 371 (2007).

${ }^{67}$ Ibid. at 374. 
We can call this approach "original methods originalism," reflecting its commitment to the methods of interpretation that characterized the Founding era. Notice that McGinnis and Rappaport's formulation of their idea does not embrace the distinction between interpretation and construction in the Whittington/Barnett sense. ${ }^{6}$

In a different vein, an important contribution to understanding the implications of the New Originalism appeared in a 2006 article by Richard Fallon, titled "Judicially Manageable Standards and Constitutional Meaning". ${ }^{99}$ Fallon does not embrace originalism, but he identified the key distinction between the meaning of the Constitution (its semantic content) and implementing rules of constitutional law (legal content):

Despite large apparent differences between originalism and nonoriginalist theories, originalist and nonoriginalist judges converge in their decisions surprisingly often. Given the strident debates among constitutional theorists, one well might wonder how so much agreement could eventuate. The reason, I would suggest, is that what we call constitutional theories or theories of constitutional interpretation are often theories about constitutional meaning that implicitly accept the permissibility of a disparity between constitutional meaning and implementing doctrine. If constitutional theories fix the meaning of the Constitution, but stipulate that implementing doctrines sometimes permissibly diverge from it, then such theories are less complete and thus less practically significant than their proponents suggest. ${ }^{70}$

Fallon's distinction between the semantic content of the Constitution and the legal content of constitutional law put the following question of

${ }^{68}$ To the extent that McGinnis and Rappaport believe that original methods recover the linguistic meaning or semantic content of the constitutional text, their theory faces severe obstacles. The public linguistic meaning of a text cannot be the legal construction that is placed upon that text by legal interpreters. Legal methods operate on the semantic content fixed by linguistic meaning: they do not create it. To think otherwise is to confuse meaning in the semantic sense with meaning in the applicative sense. See Lawrence B. Solum, "Semantic Originalism" (November 22, 2008). Illinois Public Law Research Paper No. 07-24. Available at SSRN: $<\mathrm{http}: / /$ ssrn.com/abstract $=1120244>$

${ }^{69}$ Fallon, "Manageable Standards", supra note 37; see also Michell N. Berman, "Constitutional Decision Rules," 90 Virginia Law Review 1 (2004).

${ }^{70}$ Ibid. at 1317-18 (citation omitted). 
contribution on the table: How does the semantic content contribute to legal content?

\section{G. New critics of the new originalism}

The "New Originalism" has sparked a new wave of criticism. ${ }^{71}$ The first of the new critics is Stephen Griffin, the author of "Rebooting Originalism", ${ }^{72}$ a powerful critique of the New Originalism. Griffin's critique has thoroughly absorbed the theoretical significance of the shift from original intentions to original public meaning, but it is not clear that he fully appreciates the importance of the Whittington/Barnett distinction between construction and interpretation. ${ }^{73}$ Although Griffin has a variety of important and well-argued criticisms of the new originalists, two features of his article are especially important for present purposes. First, Griffin's core argument against the New Originalism is normative: he argues that consistent and exclusive use of originalist methodology would represent a major change in interpretive practice and that originalists must therefore offer a normative justification for their theory. ${ }^{74}$ Second, Griffin's critique does not consider the possibility that original-meaning originalism might include a semantic thesis $-\mathrm{a}$ nonnormative claim about the linguistic meaning of the Constitution. ${ }^{75}$

\footnotetext{
${ }^{71}$ See, e.g., Mark Tushnet, "Heller and the New Originalism", 69 Ohio St. L.J. 609 (2008).

${ }^{72}$ Stephen M. Griffin, "Rebooting Originalism”, 2008 U. Ill. L. Rev. 1185 (2008).

73 The distinction is never discussed in a theoretical way. The first mention appears on page 34 of his essay. Ibid. at 1217.

${ }^{74}$ Ibid. at 1196-1205.

${ }^{75}$ No variant of the root word "semantic" appears in Griffin's article. Although the term "meaning" and its variants appear numerous times, there is no indication that Griffin appreciates the possibility that originalism might be a semantic theory.
} 
A second new critic is Mitchell Berman, whose critique of originalism is tendentiously titled "Originalism is Bunk” ${ }^{76}$ Berman's essay is deep and rich, raising some old objections to originalism, providing new foundations for others, and developing new positions. One of the crucial moves in his piece is his argument that the term "Originalism" (when capitalized) should be reserved for the strong claim that original meaning, whatever that might be, should trump other considerations in constitutional practice. He summarizes this claim as follows:

Originalism proper is strong originalism-the thesis that original meaning either is the only proper target of judicial constitutional interpretation or that it has at least lexical priority over any other candidate meanings the text might bear (again, contrary judicial precedents possibly excepted). [FN49] It entails (but is not equivalent to) the thesis that nothing that transpires after ratification of a particular constitutional provision, save a subsequent constitutional amendment, has operative (as opposed to evidential) bearing on what courts ought to identify as constitutional meaning. ${ }^{77}$

Berman's identification of "Originalism" (with a capital "O”) with what he calls "strong originalism" is surely mistaken. For example, Justice Scalia's (paradigmatically originalist) opinion in Heller did not dismiss precedent as irrelevant; instead, he argued that the only relevant precedent, United States $v$. Miller ${ }^{78}$ was distinguishable. ${ }^{79}$

In 2006, the New Originalist theorist, Randy Barnett, wrote "Scalia's Infidelity: A Critique of Faint-Hearted Originalism”, which explicitly disagrees with Justice Antonin Scalia on the question of force, contending that Scalia allows departure from original meaning on the basis of three

\footnotetext{
${ }^{76}$ Mitchell N. Berman, "Originalism Is Bunk", 84 N.Y.U. L. Rev. 1 at 35 (2009) [Berman, "Originalism is Bunk"]. See also Mitchell N. Berman, "Reflective Equilibrium and Constitutional Method: Lessons from John McCain and the Natural Born Citizenship Clause" in this volume. Stanley Fish criticizes "Originalism is Bunk" in "The Intentionalist Thesis Once More" in this volume.

${ }^{77}$ Berman, "Originalism is Bunk", ibid. at 22.

78307 U.S. 174 (1939).

${ }^{79}$ District of Columbia v. Heller, 554 U.S. 570 at , 128 S.Ct. 2783 at 2814 (2008) [Heller].
} 
factors: (1) precedent, (2) justiciability, and (3) settled historical practice..$^{80} \mathrm{In}$ addition to Scalia, originalists of various stripes have taken the position that original meaning can be trumped by precedent for a variety of reasons and is subject to a variety of constraints, as evidenced by the work of Kurt Lash, Lee Strang, and this author. ${ }^{81}$

Confining "Originalism" (in its focal meaning) to the view that original meaning must trump all other considerations is misleading. Moreover, this move has the unfortunate effect of defining the topography of argument in a way that eliminates plausible forms of originalism from the originalist camp, leaving only the most implausible and extreme views in contention. The equivalent move by a critic of nonoriginalism would be to define "Nonoriginalism" with a capital " $\mathrm{N}$ " as the view that "original meaning" in any form can never be considered in constitutional interpretation or construction. A more productive characterization of the debate might focus on three disagreements between originalists and nonoriginalists: (1) debates over the question whether the linguistic meaning of the Constitution should be viewed as fixed at the time each provision is framed and ratified, (2) arguments about the relative importance of the original meaning of the text versus other considerations, such as purpose, practice, precedent, and

${ }^{80}$ Randy E. Barnett, "Scalia's Infidelity: A Critique of "Faint-Hearted" Originalism", 75 U. Cin. L. Rev. 7 at 13 (2006).

${ }^{81}$ See Lash, "Originalism", supra note 45 at 1441 (stating that "popular sovereignty-based originalism ... does not require the complete abandonment of stare decisis" and "[a] theory of stare decisis that takes into account the majoritarian commitment of popular sovereignty may justify upholding an erroneous precedent"); Lawrence B. Solum, "The Supreme Court in Bondage: Constitutional Stare Decisis, Legal Formalism, and the Future Of Unenumerated Rights", 9 U. Pa. J. Const. L. 155 at 159 (2006) (arguing for originalist theory that gives trumping force to precedent); Lee J. Strang, "An Originalist Theory of Precedent: Originalism, Nonoriginalist Precedent, and the Common Good", 36 N.M. L. Rev. 419 at 420 (2006) (offering originalist theory in which "limited respect is due some nonoriginalist constitutional precedent"). 
principles, and (3) differences over the extent to which constitutional construction is constrained by the linguistic meaning of the text.

A third source of new criticism is Living Originalism, ${ }^{82}$ jointly authored by Thomas Colby and Peter Smith. They state their argument boldly:

In fact, just as with nonoriginalism, there is profound internal disagreement on the originalist side of the line. A review of originalists' work reveals originalism to be not a single, coherent, unified theory of constitutional interpretation, but rather a smorgasbord of distinct constitutional theories that share little in common except a misleading reliance on a single label. ${ }^{83}$

The question that Smith and Colby raise is an important one, and we shall return to it in Part IV of this chapter.

\section{H. District of Columbia v. Heller \& McDonald v. City of Chicago}

Supreme Court decisions that squarely address the fundamental issues of constitutional theory are rare, but District of Columbia v. Heller ${ }^{84}$ is such a decision. The key passage in the majority opinion is unmistakably originalist:

\footnotetext{
In interpreting this text, we are guided by the principle that ' $[\mathrm{t}] \mathrm{he}$ Constitution was written to be understood by the voters; its words and phrases were used in their normal and ordinary as distinguished from technical meaning. ${ }^{85}$
}

The implications of the majority's conclusion that the Second Amendment protects an individual right to possess and carry weapons were disputed by Justice Stevens and Justice Breyer in their dissenting opinions. Justice Stevens, in particular, offered a lengthy dissent, focusing in part on the

82 Thomas B. Colby \& Peter J. Smith, “Living Originalism”, 59 Duke L.J. 239 (2009) [Colby and Smith, "Living Originalism"].

${ }^{83} \mathrm{Ibid}$. at 244.

${ }^{84}$ Heller, supra note 79.

85 Ibid. at 2788 (citations omitted). 
purposes that animated the Second Amendment and raising a number of arguments relevant to the original intentions of the Framers. ${ }^{86}$

The majority opinion in Heller covers a good deal of territory, much of it contested by the dissents, but, for the purpose of completing this brief survey of the contemporary development of originalist theory, the important feature of Heller is methodological. The Court examined each of the operative words and phrases in the Second Amendment, examining the semantic content of "the people," "keep," "bear," and "arms." The Court concluded its examination as follows: "Putting all of these textual elements together, we find that they guarantee the individual right to possess and carry weapons in case of confrontation. ${ }^{\prime}{ }^{87}$ In examining each of the operative words and phrases, the Court examined evidence of usage from the period the Second Amendment was proposed and ratified. For example:

Before addressing the verbs "keep" and "bear," we interpret their object: "Arms." The 18 th-century meaning is no different from the meaning today. The 1773 edition of Samuel Johnson's dictionary defined "arms" as "weapons of offence, or armour of defence." Timothy Cunningham's important 1771 legal dictionary defined "arms" as "any thing that a man wears for his defence, or takes into his hands, or useth in wrath to cast at or strike another." 88

\section{Another example:}

The phrase "keep arms" was not prevalent in the written documents of the founding period that we have found, but there are a few examples, all of which favor viewing the right to "keep Arms" as an individual right unconnected with militia service. William Blackstone, for example, wrote that Catholics convicted of not attending service in the Church of England suffered certain penalties, one of which was that they were not permitted to "keep arms in their houses.", 89

\section{Additionally:}

${ }^{86}$ See, e.g., ibid. at 2837 n.28 (Stevens, J., dissenting).

87 Ibid. at 2797 (majority opinion).

88 Ibid. at 2791 (citations omitted).

89 Ibid. at 2792 (citations omitted). 
At the time of the founding, as now, to 'bear' meant to 'carry. ${ }^{, 90}$

Bracketing the question as to whether Heller's analysis of the linguistic evidence was correct, the methodology of Justice Scalia's majority opinion was clear: the Court focused on the evidence of the original public meaning of the text. Given the inevitable differences between judicial practice and constitutional theory, it is hard to imagine finding a clearer example of original public meaning originalism in an actual judicial decision.

Heller is not the Supreme Court's last word on originalism and the right to bear arms. In McDonald v. City of Chicago, the Supreme Court addressed the question whether the Second Amendment right to bear arms applies to the states. $^{91}$ This question implicates a long-standing constitutional controversy. Many originalists believe that the application of the Bill of Rights (including the Second Amendment) to the states should be grounded in the Privileges or Immunities Clause of the Fourteenth Amendment, but the Supreme Court's decisions have settled on the Due Process Clause as the basis for what is called "incorporation."92 Although Justice Alito's plurality opinion contains originalist passages, it relies on the nonoriginalist approach. ${ }^{93}$ Justice Thomas's concurring opinion, which provided the crucial fifth vote, rested incorporation on the Privileges or Immunities Clause instead. ${ }^{94}$

If Heller was a clear endorsement of originalism, McDonald is a mixed message at best. Prominent originalists, including Randy Barnett, have praised Justice Thomas's concurrence and criticized the majority. ${ }^{95}$ But the

90 Ibid. at 2793 (citation omitted).

91561 U.S. __ 130 S.Ct. 3020 (2010).

92 See generally Lawrence B. Solum, "Incorporation and Originalist Theory," $18 \mathrm{~J}$. Contemp. L. Issues 409, 412 (2009).

${ }^{93} 130$ S.Ct. at 3030-31 (Alito, J., plurality opinion).

94130 S.Ct. 3059 (Opinon of Thomas, J., concurring).

95 See Randy Barnett, The Supreme Court's Gun Showdown, Wall Street Journal, June 29, 2010, 
relationship of McDonald to originalism is not a simple one. On the one hand, McDonald could be read as compatible with an originalism that makes an exception for deeply entrenched precedent. On the other hand, skeptics might read McDonald as reflecting antipathy (among the plurality justices) for any doctrine that would legitimate unenumerated rights.

\section{What is Originalism?}

The question "What is originalism?," is itself ambiguous? One version of the question asks, "What is the meaning of the word "originalism?" The answer to that question is that the word is now ambiguous - having several different related senses in both scholarly and popular discourse. A second version of the questions is, "What are the necessary and sufficient conditions for content of a constitutional theory to qualify as 'originalist'?" That question should be taken off the table of serious scholarly inquiry. Originalism is not a natural kind; the term "originalism" is not used to point to the single true and correct version of originalist theory. It is simply not the case that the theories that we call "originalist" all share some set of essential characteristics. A third version of the question might be, "Which member of the family of originalist theories should be designated (or stipulated) as "originalism" (with or without a capital "O") for the purpose of theoretical discussion among constitutional theorists?" Although it would be possible to pursue the project of reaching agreement on this question, there are substantial obstacles to be overcome. No person or institution has authority to settle questions of usage in constitutional theory. There are powerful incentives for advocates and opponents of different forms of originalism (both inside and outside the academy) to use

http://online.wsj.com/article/SB10001424052748703964104575335060436777670. html. 
the term "originalism" in ways that advance their practical or theoretical agendas. None of these three versions of the what-is-originalism question identifies a fruitful line of inquiry.

Does the fact that originalism is a family of theories that cannot be explicated via a series of necessary and sufficient conditions entail the further conclusion that the question, "What is originalism?," should be abandoned altogether? Before we answer that question in the affirmative, we could consider the possibility that the family of originalist theories can be described systematically. We may be able to develop a systematic account of the similarities and differences among the varieties of originalism, and that account might allow us to identify themes or core ideas that most (if not all) originalists share.

For example, different versions of originalism offer different accounts of the determinants of original meaning. A rigorously developed typology would require a systematic investigation of all the relevant texts, but an informal survey suggests that the following versions of originalism would figure prominently: (1) original intentions originalism (the view that the meaning of the text is determined by the intentions of its authors), with subvariants for: (a) framers' intentions, (b) ratifiers' intentions, and (c) framers and ratifiers' intentions; (2) original public meaning originalism (the view that the meaning of the text is determined by the conventional semantic meaning of the words and phrases at the time each provision was framed and ratified); (3) original methods originalism (the view that the original meaning is the meaning that would have been derived given the methods of interpretation (and possibly also construction) that were employed at the time 
each provision was framed and ratified. Doubtless, there are further variations, both within these three clusters and outside them.

The diversity of theories about the determinants of original meaning does not entail the further conclusion that there is no agreement among originalists. Originalists disagree about the question as to what determines original meaning (intentions, public meanings, methods), but all or almost all of the originalist writing with which I am familiar agrees on the question as to when meaning is fixed. Original intentions originalists agree that the relevant intentions are those of the framers or ratifiers of each provision of the Constitution: thus, the original meaning of the Constitution of 1789 was fixed by facts about intentions from the period that starts with the opening of the Philadelphia Convention and ends when the ratification process was completed. Original public meaning originalists agree that the conventional semantic meaning of the words and phrases should also be determined by linguistic facts at the time each constitutional provision was framed and ratified. And a similar conclusion holds of original methods originalists.

This pattern of agreement suggests that most or almost all originalists agree that original meaning was fixed or determined at the time each provision of the constitution was framed and ratified. We might call this idea the fixation thesis. It is no surprise that originalists agree on the fixation thesis. The term "originalism" was coined to describe a family of textualist and intentionalist approaches to constitutional interpretation and construction that were associated with phrases like "original intentions," "original meaning," and "original understanding." These phrases and the word "originalist" share the root word "origin." The idea that meaning is fixed at the time of origination for each constitutional provision serves as the common 
denominator for all off these expressions. Thus, the fixation thesis might be described as a core idea, around which all or almost all originalist theories organize themselves.

Almost all originalist theories are theories of constitutional practice they have something to say about how officials (especially judges and paradigmatically Justices of the United States Supreme Court) should interpret and construe the Constitution. Although it would be theoretically possible for an originalist theory to limit itself to the purely linguistic claim that the semantic content of the Constitution is fixed at the time of origin of each provision, almost all self-identified originalists make further claims about the implications of that fact for constitutional practice.

The variations among originalists in this second dimension can be clarified by marking a distinction between semantic content and legal content. The semantic content of the constitutional text is the linguistic meaning of the document. But the term "meaning" is itself ambiguous. The constitutional text has a linguistic meaning, but that meaning is distinct from the legal implications of the text. Because we sometimes use the word "meaning" to describe such implications, the "meaning of the Constitution" can refer to set of legal rules (the body of constitutional doctrine) that mediates between the text and the decision of particular cases. The legal content of the constitutional doctrine is simply the set or rules developed by courts (and other officials) for the application of the text to particular cases.

Although originalists agree that the semantic content of the Constitution was fixed at the time each provision was framed and ratified, they disagree about the role that semantic content plays in determining legal content. In 
other words, different originalists have different views about the constraining force of original meaning. At one end of the spectrum, an originalist might believe that each and every rule of constitutional law must be identical to the original meaning of some provision of the Constitution. On that view, much of the content of contemporary constitutional doctrine would be illegitimate: since it seems clear that wide swaths of constitutional law are judicial creations. A more moderate (but still quite strong) version of originalism might adopt the view that constitutional doctrine cannot contradict the original meaning, but allow for the development of supplementary rules (for example, in the case of constitutional provisions that are vague). Further along the spectrum, some originalists might adopt the position that the original meaning should constrain constitutional doctrine, but allow for circumstances in which exceptions are legitimate. One such exception might focus on the role of precedent: some originalists may believe that the Supreme Court may legitimately adhere to precedents that are at variation with the original meaning of the text, where the restoration of the original meaning would be disruptive, upset justifiable reliance, and so forth. An even more modest version of originalism might take the position that the original meaning should govern in cases of first impression, but sanction departures from original meaning whenever a question of legal doctrine has been settled. A very weak version of originalism might require officials (such as judges) to consider the original meaning as one important factor in the determination of constitutional doctrine, but allow the original meaning to be balanced with a variety of other considerations, including precedent, contemporary social interests and values, and so forth. At this end of the spectrum, originalism will begin to merge with forms of living constitutionalism that acknowledge that text and original intentions are relevant factors in determining constitutional applications. 
Although the originalists may disagree about the constraining force of original meaning, all or almost all originalists agree that original meaning ought to play an important and substantial role in the determination of constitutional doctrine. Characteristically, originalists believe that the role of original meaning should be constraining - that is, that absent exceptional circumstances (or very weighty reasons), constitutional doctrines that contradict or contravene the semantic content of the Constitution (as fixed at the time of origin) are illegitimate. This pattern of agreement and variation suggests a second idea that forms the core around which originalist theories are organized. All or almost all originalists agree that the original meaning of the Constitution should make a substantial contribution to the content of constitutional doctrine: we might call this idea, the contribution thesis. Most originalists agree on a fairly strong version of the contribution thesis, which we might call the constraint principle (constitutional doctrine must be consistent with original meaning absent very weighty reasons). The contribution thesis forms a second core idea, around which different versions of originalism cluster. The constraint principle identifies an important nexus in that cluster - the mainstream of contemporary originalist theory.

Originalists differ in yet another important respect. Different versions of originalist theory provide different justifications for the constraining force of original meaning. Some originalists emphasize the rule of law. Others focus on the idea of popular sovereignty. Yet others emphasize the notion that the conventions of legal practice do not permit judges to deliberately overrule the linguistic meaning of the constitutional text. And still others may make the claim that adherence to original meaning is justified because it will produce better decisions in the long run than the alternative methods of constitutional 
interpretation and construction. It seems likely that many originalists will rely on some combination of these arguments, and others as well.

Of course these variations in the justifications for originalism are important, but the existence of variations at the level of normative foundation is to be expected, given the pluralism that characterizes the public culture of the American polity in general and the academy in particular. Disagreement at the level of ultimate normative foundations is perfectly consistent with agreement on core originalist principles as an operative judicial philosophy.

What is originalism? Within the domain of constitutional theory, originalism is a family of views that cluster around two central ideas, the fixation thesis and the contribution thesis. All or almost all originalists agree that the original meaning of the Constitution was fixed at the time each provision was framed and ratified. Almost all originalists agree that original meaning must make an important contribution to the content of constitutional doctrine: most originalists agree that courts should view themselves as constrained by original meaning and that very good reasons are required for legitimate departures from that constraint.

What then should we make of Colby and Smith's claim that originalism is "a smorgasbord of distinct constitutional theories that share little in common except a misleading reliance on a single label"? ${ }^{96}$ Colby and Smith are certainly correct that the term "originalism" is not used to describe a single theoretical position characterized by strong agreement among its proponents on all the important constituent elements. But this does not entail the conclusion that the only thing that unifies most (or even almost all)

${ }^{96}$ Colby \& Smith, "Living Originalism", supra note 82 at 244. 
originalist theories is "misleading reliance on a single label." The two ideas that provide the focal point of agreement among almost all originalist theories, the fixation thesis and the contribution thesis, are directly and transparently related to the label, "originalism," and the cognate notions of "original meaning" or "original understanding." Originalists agree that the "meaning" (the semantic content or linguistic meaning) of the constitutional text was fixed at the time that each provision of the constitution was framed and ratified. The fixation thesis expresses the idea that the "origin" or "time of origination" of each constitutional provision fix its meaning, which originalists call the "original meaning." There is nothing misleading about the use of the term "originalism" as the label for this view. Moreover, the family of originalist theories is organized around another central idea, the fixation thesis and its strong variant, the constraint principle. Almost all originalists agree that the original meaning ought to make a substantial and important contribution to constitutional doctrine, and most originalists make the stronger claim that this contribution ought to constrain constitutional doctrine (absent very good reasons for departure from the original meaning).

What about the important differences that remain? Does the fact that originalists disagree about important matters somehow ground an argument against the validity of the best versions of originalist theory? Initially, it is difficult to see how this argument might go. Colby and Smith are certainly correct to the extent that they argue that originalism cannot claim strong theoretical unity as a virtue - to the extent that originalists have made that claim they are simply incorrect. Originalism is a family of theories that cluster around the fixation thesis and the contribution thesis - not a single theory whose proponents agree on all the important details. 
But from the fact that originalists almost all agree about two core ideas but disagree about much else, it does not follow that no version of originalism is correct. Consider the analogous situation that holds in the natural sciences. Suppose that at one stage in the development of the theory of evolution, there were competing accounts of the mechanism by which natural selection actually occurred. (Until the discovery of DNA, the actual mechanism was uncertain.) From this fact, it would surely not follow that no version of the theory of evolution could be true or that competing versions of the theory were united only by a "misleading label." The more sensible response to theoretical disagreement is to ask the question, "Which version of the theory is right, correct, or best?" The argument that evolution must be wrong because evolutionary biologists disagree about important questions is simply a subtle variation on the genetic fallacy (no pun intended).

The originalist family of theories is actually relatively immature as academic theories go. One might read the progression from original intentions of the framers to the understandings of the ratifiers to the original public meaning of the text as a story of increasing fracture and degeneration, but the same narrative may eventually come to be seen as a story of progress and increasing sophistication.

Perhaps the most worrisome and most persistent disagreement among originalists is the one tacitly identified by Brest when he coined the term "originalism" - originalists continue to disagree about the role of "original intentions" and "original public meaning." Colby and Smith emphasize this worry:

$[\mathrm{O}]$ riginalists' specific claims that their approach alone properly treats the Constitution as a form of law and properly limits the judiciary to its appropriate role 
in a democratic society ... start from the premise that originalism (and only originalism) treats the Constitution as having a fixed and determinate meaning. Yet the meaning that a committed originalist judge would find obviously turns on the particular brand of originalism that the judge applies. And over the last thirty-five years, that meaning has been anything but fixed. A judge committed to the originalist enterprise would once have invoked original intent, and would today have the freedom to choose from a smorgasbord that includes original intent and many other originalist approaches. $^{97}$

Colby and Smith exaggerate to the extent that they claim that theoretical divergence among originalists would give judges discretion to pick and choose among originalist theories - each judge would be bound across cases to employ the theory she believed was correct, but the essence of their point is correct: there are real and substantial differences between the competing versions of originalist theory.

But the importance of the disagreement between intentionalist and public-meaning originalists should not be exaggerated. The form of intentionalism that has emerged in recent years emphasizes the semantic intentions of the authors of the constitutional text - best understood as a complex combination of the framers and ratifiers. The view is that the linguistic meaning of the text is a function of the intentions (or mental states) of its authors. Public meaning originalism takes the view that the linguistic meaning of the constitutional text is a function of its conventional semantic meaning - which is determined by patterns of usage among the relevant linguistic community.

It is possible for intended meaning and public meaning to diverge, but in the case of a legal text, such divergence will be rare in practice. The authors of the constitutional text knew that those who would read and

${ }^{97}$ Ibid. at 283. 
interpret the text would have limited access to information about idiosyncratic semantic intentions: for example, the records of the Philadelphia convention and the ratifying conventions were not publicly available in the era that immediately followed ratification. For this reason, the semantic intentions of the ratifiers are likely to closely track original public meaning - a point that is recognized by sophisticated originalists of both the intentionalist and publicmeaning varieties. And it is no surprise that this divide in originalist theory is accompanied by agreement (in principle) in application. Originalist theory must account for linguistic facts on the ground - and this means that such theories must converge in order to adequately account for the relevant evidence.

\section{Originalism and Living Constitutionalism}

The chief aim of this chapter is a modest one, to lay a foundation that can help to clarify and sharpen debates about originalist constitutional theory. The strategy has been to address the question, "What is originalism?," in the context of the evolution or development of originalist theory. In this penultimate section of the chapter, these efforts will be applied to the debate between originalists and living constitutionalists.

The first and perhaps the most important point is that it misleading to characterize controversies between originalists and living constitutionalists as a single debate. There are several versions of originalism, and it seems likely that there are many versions of "living constitutionalism." The first best approach to that fact would involve an investigation of "living constitutionalism" that parallels the exploration of originalism undertaken in this chapter, but on this occasion, we must settle for the second best approach by relying on a representative example of living constitutionalism as a 
starting point. Justice William Brennan of the United States Supreme Court offered an influential formulation of living constitutionalism:

To remain faithful to the content of the Constitution, therefore, an approach to interpreting the text must account for the existence of the substantive value choices and must accept the ambiguity inherent in the effort to apply them to modern circumstances. The Framers discerned fundamental principles through struggles against particular malefactions of the Crown: the struggle shapes the particular contours of the articulated principles. But our acceptance of the fundamental principles has not and should not bind us to those precise, at times anachronistic, contours. $^{98}$

Brennan's formulation allows us to identify two ideas that are associated with living constitutionalism. The first idea is that constitutional principles must be adapted to changing circumstances. The freedoms of speech and of the press at the time of the framing and ratification of the First Amendment had "particular contours" adapted to the communications technologies of the late-Eighteenth century. These principles will take on different contours when applied to the early Twenty-First Century world of the Internet. The second idea is somewhat different, and might be at odds with Brennan's formulation. One might believe that constitutional practice should reflect changing values as well as changing circumstances. On this view, the set of "fundamental principles" might grow and change, while the constitutional text remains the same.

Are living constitutionalism and originalism competing theories? That question can and should be reformulated as a series of inquiries. Are some versions of originalism consistent with living constitutionalism? Are other versions incompatible? Once the question is reformulated in this way, it becomes clear that there are both compatibilist and incompatibilist stories to tell about the relationship between living constitutionalism and originalism.

\footnotetext{
${ }^{98}$ William J. Brennan, Jr., "The Constitution of the United States: Contemporary Ratification", 27 S. Tex. L. Rev. 433 at 437 (1986).
} 
The compatibilist story about the relationship between living constitutionalism and originalism can be articulated via the distinction between constitutional interpretation and constitutional construction that is associated with the New Originalism. Compatibilism could be the view that originalism and living constitutionalism have separate domains. Originalism has constitutional interpretation as its domain: the linguistic meaning of the Constitution is fixed. Living constitutionalism has constitutional construction as its domain: the vague provisions of the constitution can be given constructions that change over time in order to adapt to changing values and circumstances. A fully specified living constitutionalism would have to provide a theory of constitutional construction that satisfies this description, and we can imagine that there could be a variety of such theories.

If living constitutionalism accepts the fixation thesis, some theory of semantic content, and some version of the contribution thesis, then living constitutionalism is committed to the idea that the constitutional text provides constitutional law a hard core. Originalists and some living constitutionalists could agree that the hard core of determinant constitutional meaning should not yield to changing circumstances and values and agree that in the "construction zone" created by the abstract, vague, and general provisions of the text, constitutional doctrine can "live" and "grow" in response to changing circumstances and values.

But some living constitutionalist may deny that there is a hard core. They might believe that even the core of constitutional law is malleable and subject to manipulation. That is, they might assert that the living constitution has a soft core. What then about incompatibilism? 
There are at least two different ways in which living constitutionalism could make assertions that are inconsistent with originalism. One possibility is that living constitutionalism is a theory of linguistic meaning. That is, living constitutionalists could be understood as denying the fixation thesis and asserting that the semantic meaning of a given constitutional provision changes in response to changing circumstances. But there is another version of living constitutionalism that would result in incompatibilism. Some living constitutionalists may deny what I have called the constraint principle. This version of living constitutionalism could accept the claims made by the most modest versions of originalism (for example, that original meaning should be an important factor in the determination of constitutional doctrine) but deny the claim that original meaning should strongly constrain judicial interpretation and construction of the Constitution. This view can be stated somewhat tendentiously to bring out the feature that creates the incompatibility. Some living constitutionalists may believe that courts should have the power to amend the Constitution in order to eliminate what Justice Brennan might have called the "anachronistic contours" of the constitutional text. Proponents of this view are not likely to use the word "amendment" to describe this power but that word seems an accurate characterization of the implications of their position.

Of course, this account of compatibilist and incompatibilist stories about originalism and living constitutionalism is only a sketch. Filling it out would require a careful reconstruction of the actual positions held by various participants in contemporary debates about constitutional theory. The sketch was offered to illustrate the importance of clarity in these debates. If we begin with the assumption that originalism must be incompatible with living 
constitutionalism, that assumption may well obscure the most important issues. Originalists and living constitutionalists may find common ground on very issues that they believe are the heart of the controversy. Once these misconceptions are cleared away, the new ground for contestation may look a bit different and new issues may take center stage.

\section{Conclusion}

One of the goals of this chapter has been to motivate a reorientation of the debates about originalism in constitutional theory. Constitutional theory can be practiced as politics by other means. Originalism can be viewed as the "conservative" theory, and living constitutionalism as the "liberal theory," but that picture is oversimplified at best. There is an alternative to the politicization of constitutional theory. Originalism and living constitutionalism can be debated on the intellectual merits, but that will only occur if participants in the debates view these theories in their best light and apply the principle of charity to the arguments of their opponents.

"Originalism" is an ambiguous term. The family of contemporary originalist constitutional theories contains substantial diversity, and there may be no single thesis upon which all self-described originalists agree. Despite the variety of originalist theories, there are two central ideas that serve as the focal point or core of contemporary originalism. Almost all originalists agree that the original meaning of the Constitution was fixed at the time each provision was framed and ratified. Most originalists agree that the original meaning of the Constitution should strongly constrain the content of constitutional doctrine. 